\title{
STRATEGI REKRUTMEN DAN SELEKSI TERHADAP KINERJA KARYAWAN
}

\author{
Ena Atikawati \\ Prodi Manajemen Universitas Mercu Buana Yogyakarta \\ Email: atikawati@gmail.com \\ Raswan Udjang \\ Prodi Manajemen Universitas Mercu Buana Yogyakarta \\ Email: raswan udjang@gmail.com
}

\begin{abstract}
Abstrak
Sumber daya manusia adalah aset yang sangat berharga bagi setiap organisasi dan memberikan kontribusi besar kepada organisasi karena pegawai bekerja dan bertindak untuk pencapaian tujuan organisasi. Tujuan organisasi dapat dicapai melalui tingginya komitmen organisasi yang dipengaruhi oleh karakteristik individu dan kepuasan kerja.Masalah pokok dalam penelitian ini adalah apakah proses rekrutmen dan seleksi berpengaruh terhadap kinerja karyawan pada Pondok Pesantren Wahid Hasyim Yogyakarta, diantara proses rekrutmen dan seleksi yang manakah yang paling berpengaruh dominan terhadap kinerja karyawan pada Pondok Pesantren Wahid Hasyim Yogyakarta.

Tujuan penelitian ini adalah 1) Untuk mengetahui pengaruh proses rekrutmen dan seleksi terhadap kinerja karyawan pada Pondok Pesantren Wahid Hasyim Yogyakarta, 2) Untuk mengetahui manakah faktor yang berpengaruh lebih dominan terhadap kinerja karyawan pada Pondok Pesantren Wahid Hasyim Yogyakarta. Untuk mengaplikasikan tujuan tersebut maka digunakan metode deskriptif, metode statistik deskriptif dengan bantuan sistem komputerisasi (Program Komputer PSPP versi 2016) dengan menggunakan rumus yaitu analisis regresi berganda, uji $t$ dan uji F.Berdasarkan hasil analisis mengenai pengaruh antara rekruitmen dan seleksi dengan kinerja karyawan khususnya pada Pondok Pesantren Wahid Hasyim Yogyakarta,

Pengaruh antara rekrutmen dengan kinerja karyawan Pondok Pesantren Wahid Hasyim Yogyakarta didapatkan hasil bahwa tidak ada pengaruh yang signifikan antara rekrutmen terhadap kinerja karyawan. Pengaruh antara seleksi dengan kinerja karyawan Pondok Pesantren Wahid Hasyim Yogyakarta, didapatkan hasil bahwa tidak ada pengaruh yang signifikan antara seleksi terhadap kinerja karyawan. Pengaruh antara rekrutmen dan seleksi dengan kinerja karyawan khususnya pada Pondok Pesantren Wahid Hasyim Yogyakarta didapatkan hasil bahwa tidak ada pengaruh yang signifikan antara rekrutmen dan seleksi terhadap kinerja karyawan. Variabel yang paling dominan mempengaruhi kinerja karyawan khususnya pada Pondok Pesantren Wahid Hasyim Yogyakarta adalah seleksi.

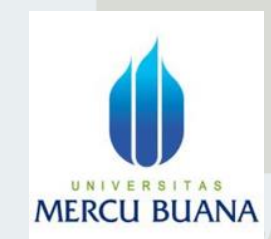

Jurnal Perilaku Dan Strategi bisnis

Vol.4 No. 1, 2016

Hal. $9-23$
\end{abstract}

Kata kunci: Sumber Daya Manusia, Pengaruh Kinerja Karyawan, Proses Rekrutmen Dan Seleksi. 


\section{PENDAHULUAN}

Pengelolaan Sumber Daya Manusia (SDM) merupakan hal yang penting dalam pencapaiaan tujuan. Umumnya pimpinan perusahaan mengharapkan kinerja yang baik dari masing-masing karyawan dalam mengerjakan tugas-tugas yang diberikan oleh perusahaan. Perusahaan menyadari bahwa Sumber Daya Manusia (SDM) merupakan modal dasar dalam proses pembangunan perusahaan bahkan nasional, oleh karena itu kualitas SDM senantiasa harus dikembangkan dan diarahkan agar tercapainya tujuan yang telah ditetapkan oleh perusahaan.

Adapun aktivitas-aktivitas manajemen sumber daya manusia ini terdiri dari : perencanaan sumber daya manusia, pengadaan, pengarahan, pengembangan, pemeliharaan, dan pemberhentian. Hal ini ditujukan agar perusahaan dapat mengelola sumber daya manusia yang baik secara efektif dan efisien.

Salah satu aktivitas dalam pengelolaan SDM adalah rekrutmen danseleksi. Rekrutmen adalah suatu proses pengumpulan sejumlah pelamar yang memiliki kualifikasi yang sesuai dengan yang dibutuhkan perusahaan, untuk dipekerjakan di dalam perusahaan (Malthis, 2001). Adapun manfaat dari rekrutmen adalah memiliki fungsi sebagai "the Right Man on The Right Place", dimana hal ini menjadi pegangan bagi para manager dalam menempatkan tenaga kerja yang ada di perusahaannya.

Rekrutmen merupakan serangkaian aktivitas untuk mencari dan memikat pelamar kerja dengan motivasi, kemampuan, keahlian dan pengetahuan yang diperlukan guna menutupi kekurangan yang diidentifikasi dalam perencanaan kepegawaian. Sedangkan seleksi merupakan proses pemilihan dari sekelompok pelamar atau orang-orang yang memenuhi kriteria untuk menempati posisi yang tersedia berdasarkan kondisi yang ada pada perusahaan.

Pondok Pesantren Wahid Hasyim Yogyakarta lembaga pendidikan non formal yang menyelenggarakan pendidikan agama secara klasikal dengan penekanan untuk kelas awal pada pedalaman ilmu alat (nahwu-soraf) dan kelas lanjutan pada pengembangan metodologi ilmu tafsir, fiqih dan ushul fiqih; Ma'had 'Aly Wahid Hasyim adalah lembaga pesantren yang menyelenggarakan kegiatan pendidikan pesantren dengan sistem perguruan tinggi, didirikan sebagai wahana pengembangan dan pendalaman ilmu-ilmu keislaman bagi para lulusan pondok pesantren yang mempunyai girah yang tinggi dalam tafaqquh $\mathrm{fi}$ adadin. Cirikhasnya adalah pengembangan dalam bidang metodologi hukum Islam (usul alfiqh) dan tafsir dengan mencoba memadukan model kajian ulama klasik dan kontemporer dan senantiasa menjaga keseimbangan antara tradisi dan metodologi, sehingga model kajian di lembaga ini tetap memelihara nilai-nilai luhur ulama masa lalu, tetapi juga akomodatif terhadap dinamika pemikiran secara selektif. Tujuan dari pendirian lembaga ini adalah untuk mencetak generasi muslim yang ahli dalam ilmu agama dan dapat merespon secara cerdas dan solutif terhadap persoalan-persoalan agama dan kehidupan keberagamaan umat Islam. Madrasah Hufadz wa Tafsir memfokuskan kepada kajianAlQur'an. Selain itu, Yayasan Pondok Pesantren Wahid hasyim juga menyelenggarakan Pendidikan Formal Madrasah Ibtida'iyah, Madrasah Tsanawiyah, dan Madrasah Aliyah, sehingga pengembangan Kompetensi Sumber Daya Manusia merupakan salah satu faktor kunci keberhasilan untuk pencapaian visi dan misi Pondok Pesantren Wahid Hasyim. Sejalan 
dengan visi, misi, dan strategi yayasan ini, Perlu diterapkan upaya yang lebih fokus dalam pengembangan SDM secara konsisten dan terus menerus.

Pengelolaan sumber daya manusia sangat diperlukan untuk efektivitas sumber daya manusia dalam suatu organisasi. Tujuan dari hal tersebut adalah untuk memberikan kepada organisasi satuan kerja yang efektif untuk mencapai tujuan studi tentang manajemen perusahaan bagaimana seharusnya perusahaan dapat mengembangkan, menggunakan dan memelihara karyawan dalam kualitas dan kuantitas yang tetap.

Oleh karena itu pihak manajemen perusahaan harus mampumemahami bagaimana cara terbaik dalam mengelola karyawan yang berasal dari latar belakang, keahlian, dan kemampuan yang berbeda-beda sehingga karyawan dapat bekerja sesuai dengan keahlian dan jenis pekerjaan yang diberikan. Penyusutan pegawai yang terjadi biasanya karena adanya pegawai yang memasuki masa pensiun, meninggal dunia atau dikeluarkan dari institusi karena melakukan pelanggaran tata tertib disiplin yang telah ditetapkan oleh Pondok Pesantren Wahid Hasyim Yogyakarta. Oleh karena itu pegawai baru yang akan menggantikannya akan memiliki masa kerja yang berbeda-beda. Rekrutmen juga dapat dilakukan untuk menambah pegawai baru kedalam suatu satuan kerja yang kegiatannya menuntut aktivitas yang tinggi. Dalam proses rekrutmen juga memerlukan adanya proses seleksi yang efektif, hal ini dilakukan untuk melakukan pemerataan pegawai sehingga kekuatan SDM yang dimiliki menjadi lebih seimbang.

Sistem perekrutan dan seleksi di dalam Pondok Pesantren Wahid Hasyim Yogyakarta tidak hanya menghasilkan pegawai yang statusnya sebagai pegawai tetap, namun untuk meningkatkan efektifitasan perusahaan, maka Pondok Pesantren Wahid Hasyim Yogyakarta juga menggunakan tenaga kerja yang berasal dari outsourching.

Kegagalan dalam melakukan sistem perekrutan tenaga kerja akan berdampak pada proses pencapaian tujuan perusahaan. Dimana kinerja pegawai dari Pondok Pesantren Wahid Hasyim Yogyakarta perlu tidak hanya mahir dalam mendidik peserta didik tetapi juga harus mampu memberikan stimulus kepada peserta didik supaya mereka mampu secara aktif mengembangkan potensi diri untuk memiliki kekuatan spiritual keagamaan, pengendalian diri, keperibadian, kecerdasan, akhlak mulia, serta keterampilan yang diperlukan dirinya , masyarakat, bangsa dan negara.

\section{RUMUSAN MASALAH}

Berdasarkan latar belakang tersebut, maka penulis mengidentifikasi masalah sebagai berikut :

1. Apakah proses rekrutmen berpengaruh terhadap kinerja karyawan Pondok Hasyim Yogyakarta.

2. Apakah proses seleksi berpengaruh terhadap kinerja karyawan pada Pondok Pesantren Wahid Hasyim Yogyakarta.

3. Apakah proses rekrutmen dan seleksi secara bersamaan berpengaruh terhadap kinerja Karyawan Pondok Pesantren Wahid Hasym Yogyakarta.

4. Diantara proses rekrutmen dan seleksi yang manakah yang paling berpengaruh dominan terhadap kinerja karyawan pada Pondok Pesantren Wahid Hasyim Yogyakarta. 


\section{TEORI DAN PENGEMBANGAN HIPOTESIS}

Sebelum mengemukakan beberapa pendapat mengenai apa yang dimaksud dengan manajemen sumber daya manusia, maka perlu dijelaskan terlebih dahulu mengenai arti manajemen itu sendiri, karena manajemen sumber daya manusia merupakan bagian dari fungsi manajemen itu sendiri.

Menurut Hasibuan (2008), manajemen adalah ilmu dan seni mengatur proses pemanfaatan sumber daya manusia dan sumber-sumber daya lainnya secara efektif dan efisien untuk mencapai suatu tujuan tertentu. Pengertian ini menjelaskan bahwa manajemen merupakan suatu ilmu dan seni dimana dalam pelaksanaannya seorang manajer perlu mencari cara dalam memberdayakan sumber daya yang dimiliki secara efektif dan efisien guna mencapai tujuan perusahaan.

Sedangkan menurut Samsudin (2010) mengemukakan bahwa manajemen adalah bekerja dengan orang-orang untuk mencapai tujuan organisasi dengan pelaksanaan perencanaan (planning), pengorganisasian (organizing), penyusunan personalia atau kepegawaian (staffing), pengarahan dan kepemimpinan (leading), dan pengawasan (controlling). Sedangkan menurut G. R Terry (dalam Samsudin 2010) mengemukakan manajemen adalah suatu proses yang khas, yang terdiri dari tindakan perencanaan, pengorganisasian, penggerakan, dan pengendalian yang dilakukan untuk menentukan serta mencapai sasaran-sasaran yang telah ditentukan melalui pemanfaatan sumber daya manusia dan sumber daya lainnya.

Seleksi merupakan bagian materi dari operasional manajemen sumber daya manusia yaitu pengadaan (procurement), sedangkan pengadaan itu sendiri terdiri dari : perencanaan, perekrutan, seleksi, penempatan, dan produksi. Proses seleksi merupakan tahap-tahap khusus yang digunakan untuk memutuskan pelamar mana yang akan diterima. Proses tersebut dimulai ketika pelamar kerja dan diakhiri dengan keputusan penerimaan. Proses seleksi merupakan pengambilan keputusan bagi calon pelamar untuk diterima atau tidak. Menurut Simamora (2004), seleksi merupakan proses pemilihan dari sekelompok pelamar yang paling memenuhi kriteria seleksi untuk posisi yang tersedia di dalam perusahaan. Sedangkan menurut Teguh (2009) menjelaskan bahwa seleksi adalah proses yang terdiri dari berbagai langkah yang spesifik dari kelompok pelamar yang paling cocok dan memenuhi syarat untuk jabatan tertentu.

Secara umum, definisi kinerja adalah hasil kerja secara kualitas dan kuantitas yang dapat dicapai oleh seorang pegawai dalam melaksanakan tugas pokok dan fungsinya sebagai pegawai sesuai dengan tanggungjawab yang dibebankan atau diberikan kepadanya. Kinerja pada dasarnya dapat dilihat dari dua segi, yaitu kinerja pegawai (perindividu) dan kinerja organisasi. Kinerja pegawai adalah hasil kerja perseorangan dalam suatu organisasi. Sedangkan kinerja organisasi adalah totalitas hasil kerja yang dicapai suatu organisasi. Istilah kinerja berasal dari kata Job Performance atau Actual Performance (Prestasi kerja atau prestasi yang sesungguhnya yang dicapai oleh seseorang).

Dalam kamus besar bahasa Indonesia dinyatakan bahwa kinerja berarti: (1) sesuatu yang dicapai, (2) prestasi yang diperlihatkan, (3) kemampuan kerja. Pengertian kinerja (Prestasi kerja) merupakan hasil kerja secara kualitas dan kuantitas yang dicapai oleh seseorang pegawai dalam melaksanakan tugasnya (Mangkunegara, 2005 : 67). Lebih 
lanjut lagi, Mangkunegara menyatakan bahwa pada umumnya kinerja dibedakan menjadi dua, yaitu kinerja individu dan kinerja organisasi, kinerja individu adalah hasil kerja karyawan baik dari segi kualitas maupun kuantitas berdasarkan standar kerja yang telah ditentukan, sedangkan kinerja organisasi adalah gabungan dari kinerja individu dengan kinerja kelompok (Mangkunegara, 2005).

Hal ini seiring dengan yang dikemukakan oleh Sarita dalam Prawirosentono (1999:2) 5, yang menyatakan bahwa: "Kinerja adalah hasil kerja yang dapat dicapai oleh seseorang atau sekelompok orang dalam suatu organisasi, sesuai dengan wewenang dan tanggung jawab masing-masing, dalam rangka upaya mencapai tujuan organisasi bersangkutan secara legal, tidak melanggar hukum dan sesuai dengan moral maupun etika". Oleh karena itu dapat disimpulkan bahwa kinerja SDM adalah prestasi kerja, atau hasil kerja (output) baik kualitas maupun kuantitas yang dicapai SDM per satuan periode waktu dalam melaksanakan tugas kerjanya sesuai dengan tanggung jawab yang diberikan kepadanya. Istilah "Kinerja" atau prestasi sebenarnya pengalih bahasaan dari bahasa Inggris "performance". Bernadin dan Russel (1993:378) yang memberikan difinisi tentang performance adalah catatan tentang hasil-hasil yang diperoleh dari fungsi-fungsi pekerjaan tertentu atau kegiatan tertentu selama kurun waktu tertentu. Pengertian kinerja menurut Rue dan Byars (1980:376) didefinisikan sebagai tingkat pencapaian hasil. Atau dengan kata lain, kinerja merupakan tingkat pencapaian tujuan organisasi. Murti dalam Mathis dan Jackson (2002) menyatakan bahwa kinerja pegawai adalah seberapa banyak para pegawai memberi konstribusi kepada perusahaan meliputi kuantitas output, kualitas output, jangka waktu, kehadiran ditempat kerja dan sikap kooperatif.

Yang menjadi hipotesis dalam penelitian ini adalah :

1. Diduga proses rekrutmen berpengaruh positif dan signifikan terhadap kinerja karyawan Pondok Pesantren Wahid Hasyim Yogyakarta.

2. Diduga proses seleksi berpengaruh positif dan signifikan terhadap kinerja karyawan Pondok Pesantren Wahid Hasyim Yogyakarta.

3. Diduga proses rekrutmen dan seleksi secara bersamaan berpengaruh positif dan signifikan terhadap kinerja karyawan Pondok Pesantren Wahid Hasyim Yogyakarta.

4. Diduga proses rekrutmen merupakan variable yang paling dominan berpengaruh terhadap kinerja karyawan Pondok Pesantren Wahid Hasyim Yogyakarta.

\section{METODE PENELITIAN \\ Populasi dan sampel}

Pada penelitian ini, penulis menjadikan karyawan dari Pondok Pesantren Wahid Hasyim Yogyakarta sebagai populasi, yang sampai tahun 2016 totalnya berjumlah empat puluh orang. Dalam hal ini akan diambil jumlah populasi secara keseluruhan dimana menurut Sugiyono dan Hair (1998:123) berpendapat bahwa pada teknik sampel random sederhana, apabila subjek penelitian jumlahnya kurang dari 100 lebih baik di ambil semua sehingga penelitianya merupakan penelitian populasi. 


\section{Metode Analisis}

Untuk membuktikan hipotesis yang telah dikemukakan maka dalam penelitian ini digunakan :

1. Analisis Deskriptif Kuantitatif

Merupakan metode yang bertujuan mengubah kumpulan data mentah menjadi bentuk yang mudah dipahami, dalam bentuk informasi yang ringkas, dimana hasil penelitian beserta analisanya diuraikan dalam suatu tulisan ilmiah yang mana dari analisi tersebut akan dibentuk suatu kesimpulan.

2. Analisis Regresi Berganda

Untuk mengetahui hubungan dan pengaruh antara proses rekrutmen dan seleksi dengan kinerja karyawan digunakan teknik analisis regresi berganda, untuk mengetahui besarnya pengaruh secara kuantitatif dari suatu perubahan (variabel $X$ ) terhadap kejadian lainnya (variabel $Y$ ). Analisis regresi menggunakan rumus persamaan regresi berganda seperti yang dikutip dalam Sugiyono (2009: 277), yaitu :

$$
Y=a+b_{1} X_{1}+b_{2} X_{2}
$$

Dimana :

$\mathrm{Y}=$ Variabel dependen, yaitu Kinerja karyawan

$\mathrm{X}_{1}=$ Variabel independen, yaitu Proses Rekrutmen

$\mathrm{X}_{2}=$ Variabel independen, yaitu Proses Seleksi

$\mathrm{a}=$ Konstanta yang merupakan rata-rata nilai $\mathrm{Y}$ pada saat nilai $\mathrm{X}_{1}$ dan $\mathrm{X}_{2}$ sama dengan nol

$b_{1}=$ Koefisien regresi parsial, mengukur rata-rata nilai $Y$ untuk tiap perubahan $X_{1}$ dengan menganggap $\mathrm{X}_{2}$ konstan.

$b_{2}=$ Koefisien regresi parsial, mengukur rata-rata nilai $Y$ untuk tiap perubahan $X_{2}$ dengan menganggap $X_{1}$ konstan.

3. Analisis Koefisien Determinasi $\left(R^{2}\right)$

Pada model linear berganda ini, akan dilihat besarnya kontribusi untuk variabel bebas secara bersama-sama terhadap variabel terikatnya dengan melihat besarnya koefisien determinasi totalnya $\left(R^{2}\right)$. Jika $\left(R^{2}\right)$ yang diperoleh mendekati 1 (satu) maka dapat dikatakan semakin kuat. model tersebut menerangkan hubungan variabel bebas terhadap variabel terikat. Sebaliknya jika $\left(R^{2}\right)$ makin mendekati 0 (nol) maka semakin lemah pengaruh variabel-variabel bebas terhadap variabel terikat.

4. Pengujian hipotesis (Uji F dan T)

Uji ini digunakan untuk mengetahui pengaruh bersama-sama variabel bebas terhadap

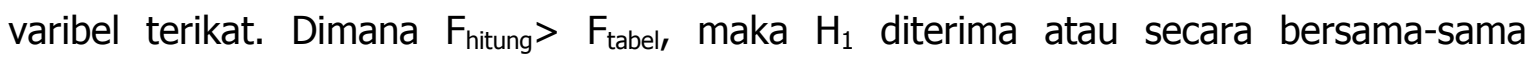
variabel bebas dapat menerangkan variabel terikatnya secara serentak. Sebaliknya apabila $\mathrm{F}_{\text {hitung }}<\mathrm{F}_{\text {tabel, }}$ maka $\mathrm{H}_{0}$ diterima atau secara bersama-sama variabel bebas tidak memiliki pengaruh terhadap variabel terikat. Untuk mengetahui signifikan atau tidak pengaruh secara bersama-sama variabel bebas terhadap variabel terikat maka digunakan probability sebesar $5 \%(a=0,05)$.

Jika sig > à $(0,05)$, maka H0 diterima H1 ditolak.

Jika sig < à $(0,05)$, maka H0 ditolak H1 diterima.

Sedangkan Uji T digunakan untuk mengetahui apakah masing-masing variabel bebasnya secara sendiri-sendiri berpengaruh secara signifikan terhadap variabel terikatnya. Dimana 
Ttabel> Thitung, H0 diterima. Dan jika Ttabel< Thitung, maka H1 diterima, begitupun jika sig > à $(0,05)$, maka H0 diterima H1 ditolak dan jika sig < à $(0,05)$, maka H0 ditolak H1 diterima.

5. Pengukuran Instrumen Penelitian

Menurut Sugiyono (2009 : 132) skala Likert digunakan untuk mengukur sikap, pendapat, dam persepsi seseorang atau sekelompok orang tentang fenomena sosial. Sehingga untuk mengetahui pengukuran jawaban responden pada penelitian ini yang mana menggunakan instrument penelitian berupa kuisioner, penulis menggunakan metode skala Likert (Likert's Summated Ratings).

Dalam pengukuran jawaban responden, pengisian kuesioner proses rekrutmen dan proses seleksi terhadap kinerja karyawan diukur dengan menggunakan skala likert, dengan tingkatan sebagai berikut :
1. Jawaban Sangat Setuju
diberi bobot 5
2. Jawaban Setuju
diberi bobot 4
3. Jawaban Ragu-ragu
diberi bobot 3
4. Jawaban Tidak Setuju
diberi bobot 2
5. Jawaban Sangat Tidak Setuju diberi bobot 1

Instrumen penelitian (kuisioner) yang baik harus memenuhi persyaratan yaitu valid dan reliabel. Untuk mengetahui validitas dan reliabilitas kuesioner perlu dilakukan pengujian atas kuisioner dengan menggunakan uji validitas dan uji reliabilitas. Karena validitas dan reliabilitas ini bertujuan untuk menguji apakah kuesioner yang disebarkan untuk mendapatkan data penelitian adalah valid dan reliabel, maka untuk itu, penulis juga akan melakukan kedua uji ini terhadap instrumen penelitian (kuisioner), yaitu:

1. Uji reliabilitas dimaksudkan untuk mengukur suatu kuesioner yang merupakan indikator dari variabel. Reabilitas diukur dengan uji statistik cronbach's alpha (a). Suatu variabel dikatakan reliabel jika memberikan nilai cronbach' alpha $>0,60$.

2. Uji validitas digunakan untuk mengukur sah atau valid tidaknya suatu kuesioner. Uji validitas dilakukan dengan melakukan korelasi bivariate antara masing-masing skor indikator dengan total skor variabel.

6. Definisi Operasional variabel

Tabel 1.

Ringkasan Definisi Operasional Variabel

\begin{tabular}{|l|l|l|}
\hline \multicolumn{1}{|c|}{ Variabel } & \multicolumn{1}{|c|}{ Definisi Operasional } & \multicolumn{1}{c|}{ Indikator } \\
\hline Proses Rekrutmen $\left(\mathrm{X}_{1}\right)$ & $\begin{array}{l}\text { Proses atau tindakan } \\
\text { yang dilakukan oleh } \\
\text { organisasi untuk } \\
\text { mendapatkan }\end{array}$ & $\begin{array}{l}\text { 1. Dasar sumber penarikan } \\
\text { karyawan }\end{array}$ \\
& $\begin{array}{l}\text { 2. Sumber Karyawan } \\
\text { tambahan pegawai } \\
\text { melalui beberapa } \\
\text { tahapan }\end{array}$ & $\begin{array}{l}\text { 3. Metode penarikan } \\
\text { karyawan }\end{array}$ \\
& & \\
\hline
\end{tabular}




\begin{tabular}{|l|l|l|}
\hline Proses Seleksi $\left(\mathrm{X}_{2}\right)$ & $\begin{array}{l}\text { Proses pemilihan dari } \\
\text { sekelompok pelamar } \\
\text { yang paling memenuhi } \\
\text { kriteria seleksi untuk } \\
\text { posisi yang tersedia di } \\
\text { dalam perusahaan }\end{array}$ & $\begin{array}{l}\text { 2. Referensi } \\
\text { 3. Pengalaman } \\
\text { 4. Kemampuan } \\
\text { menggunakan bahasa } \\
\text { Inggris }\end{array}$ \\
& $\begin{array}{l}\text { 5. Kesehatan } \\
\text { 6. Tes tertulis }\end{array}$ \\
\hline Kinerja (Y) & $\begin{array}{l}\text { 7. Tes wawancara } \\
\text { Hasil pencapaian kerja } \\
\text { secara kualitas dan } \\
\text { kuantitas yang dicapaioleh } \\
\text { seorang pegawai } \\
\text { dalam melaksanakan } \\
\text { tugasnya sesuai } \\
\text { dengan tanggung } \\
\text { jawab yang diberikan } \\
\text { kepadanya }\end{array}$ & $\begin{array}{l}\text { 1. Hasil kerja } \\
\text { 2. Perilaku kerja } \\
\text { 3. Sifat pribadi }\end{array}$ \\
& \\
\hline
\end{tabular}

\section{HASIL PENELITIAN}

Deskripsi profil responden menguraikan atau menggambarkan indentitas responden yang dijadikan sebagai sampel penelitian. Dalam pembahasan profil responden ditetapkan empat puluh responden. Dimana perlu penyebaran kuesioner kepada responden yang menunjukkan bahwa semua responden telah mengembalikan kuesioner dan telah diisi secara lengkap dan benar.

Kemudian perlu ditambahkan bahwa dalam deskripsi profil responden maka yang ditekankan adalah berdasarkan jenis kelamin, umur, tingkat pendidikan terakhir dan berdasarkan lama kerja. Deskripsi profil responden berdasarkan jenis kelamin (gender).Deskripsi profil responden berdasarkan jenis kelamin yaitu menguraikan atau menggambarkan jenis kelamin responden. Hal ini dapat dikelompokkan menjadi 2 kelompok yaitu: laki-laki dan perempuan. deskripsi profil responden menurut jenis kelamin (gender), yang menunjukkan bahwa frekuensi antara laki-laki dengan perempuan jumlahnya sama, laki-laki tidak lebih banyak dari perempuan, begitupun sebaliknya.

Uji instrument penelitian digunakan untuk menguji tingkat keakuratan data dalam pengujian hipotesis. Sehingga dalam uji instrument diterapkan uji validitas dan reliabilitas.

\section{Uji Validitas}

Uji validitas digunakan untuk mengukur ketepatan atau kecermatan suatu instrument penelitian, menurut Dwi (2009, hal. 90) dalam penentuan layak atau tidaknya suatu item yang digunakan biasanya dilakukan uji signifikan, artinya dianggap valid jika berkorelasi signifikan terhadap total, atau jika melakukan penilaian langsung jika batas minimal korelasi 0,30 . 
Uji validitas instrumen penelitian ini telah dilakukan pada penelitian yang dilakukan oleh Nugroho (2012), seperti yang terlampir dalam tabel 5.8, tabel 5.9 dan tabel 5.10 berikut ini.

Tabel 2.

Uji Validitas Untuk Variabel Rekrutmen

\begin{tabular}{|l|l|l|l|l|}
\hline $\begin{array}{l}\text { Kode } \\
\text { Pertanyaan }\end{array}$ & Korelasi & Sig & $\begin{array}{l}\text { Batas } \\
\text { Minimal } \\
\text { Korelasi }\end{array}$ & Keputusan \\
\hline Pr1 & 0,722 & 0,000 & 0,30 & Valid \\
Pr2 & 0,763 & 0,000 & 0,30 & Valid \\
Pr3 & 0,877 & 0,000 & 0,30 & Valid \\
Pr4 & 0,904 & 0,000 & 0,30 & Valid \\
Pr5 & 0,804 & 0,000 & 0,30 & Valid \\
Pr6 & 0,723 & 0,000 & 0,30 & Valid \\
Pr7 & 0,714 & 0,000 & 0,30 & Valid \\
\hline
\end{tabular}

Sumber: SPSS relase 19

Tabel 3.

Uji Validitas Untuk Variabel Seleksi Karyawan

\begin{tabular}{|l|l|l|l|l|}
\hline $\begin{array}{l}\text { Kode } \\
\text { Pertanyaan }\end{array}$ & Korelasi & Sig & $\begin{array}{l}\text { Batas Minimal } \\
\text { Korelasi }\end{array}$ & Keputusan \\
\hline Ps1 & 0,877 & 0,000 & 0,30 & 0,30 \\
Ps2 & 0,846 & 0,000 & 0,30 & Valid \\
Ps3 & 0,879 & 0,000 & 0,30 & Valid \\
Ps4 & 0,900 & 0,000 & 0,30 & Valid \\
Ps5 & 0,083 & 0,000 & 0,30 & Valid \\
Ps6 & 0,083 & 0,000 & 0,30 & Valid \\
Ps7 & 0,780 & 0,000 & Valid \\
\hline
\end{tabular}

Sumber: SPSS relase 19

Tabel 4.

Uji Validitas Untuk Variabel Kinerja Karyawan

\begin{tabular}{|l|l|l|l|l|}
\hline $\begin{array}{l}\text { Kode } \\
\text { Pertanyaan }\end{array}$ & Korelasi & Sig & $\begin{array}{c}\text { Batas Minimum } \\
\text { Korelasi }\end{array}$ & Keputusan \\
\hline Kk1 & 0,671 & 0,000 & 0,30 & Valid \\
Kk2 & 0,694 & 0,000 & 0,30 & Valid \\
Kk3 & 0,748 & 0,000 & 0,30 & Valid \\
Kk4 & 0,584 & 0,000 & 0,30 & Valid \\
Kk5 & 0,683 & 0,000 & 0,30 & Valid \\
Kk6 & 0,674 & 0,000 & 0,30 & Valid \\
Kk7 & 0,671 & 0,000 & 0,30 & Valid \\
\hline
\end{tabular}

Sumber: SPSS relase 19 
Hasil uji validitas untuk variabel rekrutmen pada tabel 5.8 dengan 7 item pertanyaan didapatkan hasil nilai korelasi sudah diatas dari 0,30 yaitu 0,714 - 0,904. Karena nilai korelasi diatas dari 0,30 dengan setiap pertanyaan berkorelasi signifikan ( $a<$ 0,05 ) berarti dapat dikatakan bahwa semua item pertanyaan dikatakan valid. Kemudian, hasil uji validitas untuk variabel seleksi karyawan pada tabel 5.9 yang memiliki 7 item pertanyaan memiliki korelasi antara 0,780 -0,900, sedangkan batas minimal nilai korelasi 0,30 dengan setiap pertanyaan berkorelasi signifikan $(a<0,05)$ berarti dapat dikatakan bahwa semua item pertanyaan dikatakan valid. Selanjutnya, dari hasil uji validitas untuk variabel kinerja pada tabel 5.10 diperoleh nilai korelasi dari setiap instrument penelitian lebih dari 0,30 yakni 0,584-0,748 dan nilai $a<0,05$ berarti semua item pertanyaan dapat dikategorikan valid.

\section{Uji Reliabilitas}

Uji reliabilitas digunakan untuk mengetahui konsistensi alat ukur, apakah alat ukur yang digunakan dapat diandalkan dan tetap konsisten jika pengukuran tersebut diulang. Menurut Dwi (2009, hal. 98) bahwa reliabilitas kurang dari 0,60 kurang baik, sedangkan 0,70 dapat diterima dan 0,80 adalah baik. Oleh karena itulah akan disajikan hasil uji reliabilitas yang dapat dilihat pada tabel berikut ini :

Tabel 5.

Hasil Uji Reliabilitas

\begin{tabular}{|l|l|l|l|l|l|}
\hline No & $\begin{array}{l}\text { Variabel } \\
\text { Penelitian }\end{array}$ & $\begin{array}{l}\text { Jumlah } \\
\text { Item } \\
\text { Pertanyaan }\end{array}$ & $\begin{array}{l}\text { Cronbach's } \\
\text { Alpha }\end{array}$ & $\begin{array}{l}\text { Batas } \\
\text { Cronbach's } \\
\text { Alpha }\end{array}$ & Keterangan \\
\hline 1 & Rekrutmen & 7 & 0,897 & 0,60 & Reliable/andal \\
2 & Seleksi & 7 & 0,929 & 0,60 & Reliable/Andal \\
3 & Kinerja & & 0,802 & 0,60 & Reliable/Andal \\
\hline \multicolumn{2}{|l}{ Jumlah Pertanyaan } & 21 & & & \\
\hline
\end{tabular}

Sumber: Data diolah dengan SPSS

Uji reabilitas intrumen dalam penelitian ini telah dilakukan pada penelitian Nugroho (2012) seperti yang terlampir dalam tabel 5.11. Hasil uji reliabilitas dengan 3 variabel dan 21 item pertanyaan didapatkan hasil cronbach's alpha ketiga variabel antara 0,802 - 0,929. Hal ini dapat dikatakan bahwa dari 21 item pertanyaan yang akan digunakan semua item pertanyaan dapat dikategorikan andal/reliabel sebab memiliki cronbach's alpha di atas dari 0,60. Dengan demikian dapat dikatakan bahwa semua item pertanyaan yang telah diolah memiliki tingkat keandalan yang tinggi dalam proses pengujian hipotesis.

Analisis regresi digunakan dalam menguji seberapa besar pengaruh antara seleksi dan rekrutmen terhadap kinerja karyawan. Oleh karena itulah akan disajikan hasil olahan data regresi yang dapat disajikan pada tabel berikut ini : 
Tabel 6

Olahan Data Regresi Dan Korelasi

\begin{tabular}{|c|c|c|c|c|c|c|}
\hline \multirow[t]{2}{*}{ Model } & \multicolumn{2}{|c|}{$\begin{array}{l}\text { Unstandardized } \\
\text { Coeficient }\end{array}$} & \multirow{2}{*}{$\begin{array}{l}\text { Standardized } \\
\text { Coeficient } \\
\text { Beta }\end{array}$} & \multirow[t]{2}{*}{ t hitung } & \multirow[t]{2}{*}{ Sig } & \multirow[t]{2}{*}{ Keterangan } \\
\hline & $B$ & $\begin{array}{l}\text { Std. } \\
\text { Eror }\end{array}$ & & & & \\
\hline 1 (Constant) & 16,17 & 5,66 & 0,00 & & & \\
\hline Rekrutmen & 0,14 & 0,14 & 0,16 & 0,97 & 0,34 & \\
\hline Seleksi & 0,18 & 0,14 & 0,20 & 1,25 & 0,22 & \\
\hline \multicolumn{3}{|l|}{$R=0,23$} & \multicolumn{4}{|c|}{$F$ hit $=1,08$} \\
\hline \multicolumn{3}{|l|}{$R^{2}=0,05$} & \multicolumn{4}{|c|}{ Sign $=0,35$} \\
\hline
\end{tabular}

Sumber : Data diolah dengan SPSS

Tabel 5.12 yakni hasil olahan data regresi, maka akan dapat disajikan persamaan regresi yaitu sebagai berikut :

$$
Y=16,17+0,14 X_{1}+0,18 X_{2}
$$

Dari hasil persamaan regresi yang telah diuraikan di atas, maka dengan nilai koefisien $X_{1}=0,14$ menunjukkan bahwa rekrutmen dengan kinerja karyawan berpengaruh positif. Dimana semakin baik pelaksanaan rekrutmen maka kinerja karyawan akan semakin meningkat. Dengan kata lain bahwa dengan pelaksanaan rekrutmen maka akan mempengaruhi peningkatan kinerja karyawan. Sedangkan koefisien $\mathrm{X}_{2}=0,18$ dapat diartikan bahwa seleksi karyawan dapat berpengaruh positif terhadap kinerja karyawan. Hal ini dapat diinterprestasikan bahwa semakin baik seleksi karyawan maka akan dapat meningkatkan kinerja karyawan. Kemudian dapat dilakukan pengujian parsial antara kedua variabel (rekrutmen dan seleksi) terhadap kinerja karyawan yang dapat diuraikan sebagai berikut :

1. Uji parsial rekrutmen dengan kinerja karyawan

Uji parsial antara rekrutmen dengan kinerja diperoleh nilai t hitung $=0,97$ dan sig $=0,34$. Karena nilai sig 0,34 > 0,05 dapatlah disimpulkan bahwa rekrutmen berpengaruh tidak signifikan terhadap kinerja karyawan, sebab nilai sig $>0,05$, sehingga dapatlah dikatakan tidak ada pengaruh yang signifikan antara rekrutmen dengan kinerja karyawan.

2. Uji parsial seleksi dengan kinerja karyawan

Dalam pengujian secara parsial yaitu antara seleksi dengan kinerja karyawan diketahui bahwa dengan nilai thitung $=1,25$ dan sig $=0,22$. Karena nilai sig $=0,22>$ 0,05 hal ini dapatlah dikatakan tidak ada pengaruh yang signifikan antara seleksi dengan kinerja karyawan.

Berdasarkan hasil uji parsial yang sebagaimana telah diuraikan di atas maka dapat dikatakan bahwa tidak ada pengaruh signifikan antara rekrutmen dan seleksi dengan kinerja karyawan. Kemudian dari hasil uji korelasi (R) diperoleh nilai korelasi 0,23, sehingga dapat dikatakan bahwa ada hubungan yang positif namun tidak kuat antara rekrutmen dan seleksi karyawan terhadap kinerja karyawan. Kemudian dilihat dari nilai R2 $=0,05$ yang dapat diartikan bahwa sebesar 0,05 (5\%) sumbangan variabel rekrutmen dan seleksi dapat 
menjelaskan variabel dependent, sedangkan sisanya sebesar 95\% (0,05 - 1 x 100) dipengaruhi oleh variabel lain yang tidak dimasukkan dalam model penelitian ini.

Berdasarkan pengujian regresi secara simultan diperoleh nilai $F$ hitung $=1,08$ atau sig $=0,35$, karena nilai sig $=0,35>0,05$ berarti seleksi dan rekrutmen secara bersama-sama tidak berpengaruh signifikan terhadap kinerja karyawan.

Sedangkan variabel yang paling dominan mempengaruhi kinerja karyawan adalah seleksi. Alasannya karena nilai seleksi memiliki standar koefisien regresi yang terbesar $(0,18)$ jika dibandingkan dengan nilai koefisien regresi rekrutmen $(0,14)$, selain itu memiliki nilai t hitung yang terbesar $(1,25)$ jika dibandingkan dengan rekrutmen karyawan $(0,97)$.

Berdasarkan hasil analisis yakni pengujian regresi secara parsial dan secara simultan antara regresi dan korelasi ternyata rekrutmen dan seleksi berpengaruh positif, namun tidak berpengaruh signifikan terhadap kinerja karyawan. Hal ini dapat disajikan hasil pembahasan dalam penelitian ini yaitu sebagai berikut:

1. Pengaruh rekrutmen dengan kinerja karyawan

Pengaruh rekrutmen dengan kinerja karyawan melalui uji regresi menunjukkan adanya pengaruh yang positif antara rekrutmen dengan kinerja karyawan. Hal ini menunjukkan bahwa pelaksanaan rekrutmen khususnya pada Pondok Pesantren Wahid Hasyim Yogyakarta berdampak terhadap kinerja karyawan, dimana semakin baik rekrutmen maka semakin baik kinerja karyawan di Pondok Pesantren Wahid Hasyim Yogyakarta.

Kemudian melalui hasil uji parsial yang sebagaimana telah dilakukan, tidak terdapat pengaruh yang signifikan antara rekrutmen dengan kinerja karyawan. Hal berbeda dengan penelitian yang dilakukan oleh Nugroho (2012) pada PT. Angkasa Pura I (Persero) Bandara Internasional Sultan Hasanudin Makasar dan penelitian Kresnani (2010) mengenai pengaruh proses rekrutmen dan seleksi terhadap kinerja karyawan pada PT. PLN (Persero) Kantor Pusat yang mendapatkan hasil signifikan antara rekrutmen terhadap kinerja karyawan. Namun, penelitian ini memiliki hasil yang sama dengan penelitian yang dilakukan oleh Andika (2011) mengenai pengaruh rekrutmen terhadap kinerja karyawan pada PT. Perkebunan Nusantara III Medan. Dimana hasil analisis yang dilakukan, didapatkan hasil bahwa perekrutan tidak berpengaruh signifikan terhadap kinerja karyawan. Hal ini disebabkan karena 55,5\% dalam penelitian Andika (2011) pengaruh kinerja disebabkan oleh faktor lain seperti pemberian kompensasi gaji, bonus, maupun pemberian fasilitas seperti pemberian rumah bagi karyawan. Oleh karena itu, pada penelitian ini kemungkinan terdapat faktor lain yang lebih besar mempengaruhi kinerja sebagaimana penelitian yang dilakukan oleh Hendriawan (2014) bahwa gaya kepemimpinan dan budaya organisasi berpengaruh signifikan terhadap kinerja karyawan pada PT Dwimitra Multiguna Sejahtera di Kabupaten Konawe Utara Provinsi Sulawesi Tenggara. Selain itu, penelitian yang dilakukan Kurniadi (2012) menunjukkan hasil bahwa kompensasi dan motivasi berpengaruh signifikan terhadap kinerja karyawan di Apotek Berkah.

2. Pengaruh seleksi dengan kinerja karyawan

Berdasarkan hasil uji regresi yakni antara seleksi karyawan dengan kinerja karyawan, didapatkan hasil bahwa terdapat pengaruh yang positif dengan kinerja karyawan. Dimana seleksi dapat diikuti oleh peningkatan kinerja karyawan. 
Berdasarkan hasil uji parsial, tidak terjadi pengaruh yang signifikan antara seleksi dengan kinerja karyawan sebab memiliki nilai sig $>0,05$. Hal ini berbeda dengan hasil penelitian yang dilakukan oleh Angga (2010) bahwa ada pengaruh yang signifikan antara seleksi dengan kinerja karyawan baik secara simultan maupun secara parsial. Selain itu, berdasarkan hasil penelitian Nugroho (2012) pada PT. Angkasa Pura I (Persero) Bandara Internasional Sultan Hasanudin Makasar dimana terdapat pengaruh yang signifikan antara seleksi terhadap kinerja. Namun, berdasarkan penelitian yang dilakukan oleh Kurniati (2014) mengenai Pengaruh Mengenai Rekrutmen, Seleksi dan Gaji Terhadap Kinerja Karyawan pada PT Bank Syariah Mandiri Cabang Yogyakarta yang didapatkan hasil bahwa seleksi dan rekrutmen terhadap kinerja, dan faktor yang paling dominan mempengaruhi kinerja adalah gaji.

3. Pengaruh rekrutmen dan seleksi terhadap kinerja karyawan

Hasil uji hipotesis yang sebagaimana telah dilakukan ada pengaruh yang signifikan antara rekrutmen dan seleksi terhadap kinerja karyawan, sedangkan dari hasil penelitian yang telah dilakukan ada pengaruh yang tidak signifikan antara rekrutmen dan seleksi terhadap kinerja karyawan, dengan demikian hipotesis pertama yang diajukan dapat dikatakan tidak terbukti. Hal ini kemungkinan besar dalam penelitian ini, kinerja karyawan Pondok Pesantren Wahid Hasyim Yogyakarta tidak terlalu dipengaruhi oleh pelaksanaan rekrutmen dan seleksi, mengingat banyak faktor yang mempengaruhi kinerja karyawan seperti gaya kepemimpinan, kompensasi gaji, inisiatif, kemampuan, keahlian, pengetahuan, efektifitas dan efesiensi. Seperti penelitian yang dilakukan oleh Melati (2011) mengenai faktor-faktor yang mempengaruhi kinerja pegawai Kementrian Keuangan adalah orientasi tujuan dan gaya kepemimpinan. Selain itu, dlam penelitian yang dilakukan oleh Patiran (2010) mengenai Analisis Faktor-Faktor Yang Mempengaruhi Kinerja Pegawai Negeri Sipil (PNS) antara lain disiplin kerja, pendidikan, motivasi dimana faktor yang paling berpengaruh terhadap kinerja PNS adalah disiplin kerja dengan hubungan yang positif sangat kuat.

4. Faktor yang paling dominan dalam mempengaruhi kinerja karyawan

Berdasarkan penelitian ini, didapatkan hasil bahwa variabel yang paling dominan mempengaruhi kinerja karyawan adalah proses seleksi. Hal ini ditunjukkan dari nilai $t$ hitung yang terbesar jika dibandingkan dengan variabel rekrutmen. Dengan demikian hipotesis kedua yang diajukan terbukti. Hasil ini sama dengan penelitian yang dilakukan oleh Nugroho (2012) pada PT. Angkasa Pura I (Persero) Bandara Internasional Sultan Hasanudin Makasar bahwa seleksi lebih dominan mempengaruhi kinerja karyawan dibanding pelaksanaan rekrutmen. Selain itu, berdasarkan penelitian yang dilakukan oleh Yullyanti (2009) mengenai Analisis Proses Rekrutmen dan Seleksi pada Kinerja Pegawai didapatkan hasil bahwa rekrutmen berpengaruh secara tidak langsung terhadap kinerja melalui proses seleksi. Sehingga, hal ini mendukung hasil penelitian ini bahwa faktor yang paling dominan yang mempengaruhi kinerja adalah seleksi.

\section{KESIMPULAN}

Berdasarkan hasil analisis dan pembahasan yang telah diuraikan sebelumnya maka akan disajikan beberapa kesimpulan yaitu sebagai berikut : 
1. Berdasarkan hasil Uji parsial antara rekrutmen dengan kinerja karyawan pada Pondok Pesantren Wahid Hasyim Yogyakarta diperoleh nilai thitung $=0,97$ dan sig $=0,34$. Karena nilai sig 0,34 > 0,05 dapatlah disimpulkan bahwa rekrutmen berpengaruh tidak signifikan terhadap kinerja karyawan, sebab nilai sig $>0,05$. Dengan demikian hipotesis tidak terbukti.

2. Berdasarkan hasil pengujian secara parsial yaitu antara seleksi dengan kinerja karyawan pada Pondok Pesantren Wahid Hasyim Yogyakarta, diketahui bahwa dengan nilai thitung $=1,25$ dan sig $=0,22$. Karena nilai sig $=0,22>0,05$ hal ini dapatlah dikatakan tidak ada pengaruh yang signifikan antara seleksi dengan kinerja karyawan. Dengan demikian hipotesis tidak terbukti.

3. Berdasarkan hasil pengujian regresi secara simultan yaitu antara rekrutmen dan seleksi terhadap kinerja karyawan pada Pondok Pesantren Wahid Hasyim Yogyakarta, diperoleh nilai $\mathrm{F}$ hitung $=1,08$ atau sig $=0,35$, karena nilai sig $=0,35>0,05$ berarti seleksi dan rekrutmen secara bersama-sama tidak berpengaruh signifikan terhadap kinerja karyawan. Dengan demikian hipotesis tidak terbukti.

4. Variabel yang paling dominan mempengaruhi kinerja karyawan pada Pondok Pesantren Wahid Hasyim Yogyakarta Yogyakarta adalah seleksi, Alasannya karena nilai seleksi memiliki standar koefisien regresi yang lebih besar besar $(0,18)$ jika dibandingkan dengan nilai koefisien regresi rekrutmen $(0,14)$, selain itu memiliki nilai thitung yang lebih besar $(1,25)$ jika dibandingkan dengan rekrutmen karyawan $(0,97)$, sehingga hipotesis keempat dapat dikatakan tidak terbukti.

\section{SARAN PENELITIAN YANG AKAN DATANG}

Adapun saran-saran yang dapat diberikan sehubungan dengan hasil penelitian ini adalah sebagaiberikut :

1. Disarankan agar Pondok Pesantren Wahid Hasyim YogyakartaYogyakarta, hendaknya lebih memperhatikan kinerja karyawan yang sesuai dengan kompetensi dimana setiap karyawan yang dimiliki dapat menyelesaikan atau menangani pekerjaan.

2. Disarankan untuk meneliti lebih lanjut mengenai faktor-faktor lain yang mempengaruhi kinerja karyawan Pondok Pesantren Wahid Hasyim YogyakartaYogyakarta mengingat hasil dari penelitian ini bahwa seleksi dan rekrutmen hanya berpengaruh $5 \%$ terhadap kinerja karyawan.

\section{DAFTAR PUSTAKA}

Budiharjo, Andreas. 2011. Organisasi : Menuju Pencapaian Kinerja Optimum. Jakarta : Prasetya Mulya Publishing.

Gomes, C Faustino.2010. Manajemen Sumber Daya Manusia. Yogyakarta: AndiOffset.

Handoko T. Hani, 2008, Manajemen Personalia dan Sumber Daya Manusia, edisi kedua, Penerbit : BPFE, Yogyakarta.

Hasibuan, Malayu, SP. 2008, Manajemen Sumber Daya Manusia, edisi revisi, Cetakan ketujuh, Penerbit : Bumi Aksara, Jakarta.

Malayu S.P. Hasibuan. 2010. Manajemen Sumber Daya Manusia. Jakarta: PT. Bumi Aksara. 
Malthis, Robert, L dan John H. Jackson, 2001, Human Resource Management (Manajemen Sumber Daya Manusia), Edisi Sepuluh, Terjemahan : Diana Angelica, Penerbit : Salemba Empat, Jakarta.

Margono. 2010. Metodologi Penelitian. Jakarta: PT. Rineka Cipta.

Nawawi, Hadari, 2008, Manajemen Sumber Daya Manusia Untuk Bisnis yang Kompetitif, cetakan keempat, Penerbit : Gadjah Mada University Press, Yogyakarta.

Rivai, Veithzal, 2009, Manajemen Sumber Daya Manusia untuk Perusahaan, edisi kedua, Penerbit : Rajawali Pers, Jakarta.

Robbbins dan Judge. 2007. Perilaku Organisasi, Buku 1 dan 2. Jakarta : Salemba Empat.

Samsudin, H, Sadeli, 2010, Manajemen Sumber Daya Manusia, Penerbit

Pustaka Setia, Bandung

Simamora, Henry, 2004, Manajemen Sumber Daya Manusia, edisi ketiga, cetakan pertama, Penerbit : YKPN, Yogyakarta

Soekidjo Notoatmodjo. 2009. Pengembangan Sumber Daya Manusia. Jakarta : Rineka Cipta.

Samsudin, H, Sadeli, 2010, Manajemen Sumber Daya Manusia, Penerbit

Pustaka Setia, Bandung.

Sutrisno Edy. 2010. Manajemen Sumber Daya Manusia. Jakarta : Kencana Predana Media Grup.

Umar, Husein. 2008. Riset Sumberdaya Manusia Dalam Organisasi. Jakarta: PT Gramedia Pustaka Utama.

Wirawan. 2007. Budaya dan Iklim Organisasi. Jakarta : Salemba Empat 